\title{
IT as a part of intellectual capital and its impact on the performance of business entities
}

\author{
Ksenija Černe ${ }^{1, \dagger}$ and Darko Etinger ${ }^{2}$ \\ ${ }^{1}$ Faculty of Economics and Tourism "Dr. Mijo Mirković", Juraj Dobrila University of \\ Pula, Zagrebačka 30, 52100 Pula, Croatia \\ E-mail:〈ksenija.cerne@unipu.hr〉 \\ ${ }^{2}$ Department of Information and Communication Technologies, Juraj Dobrila University \\ of Pula, Zagrebačka 30, 52100 Pula, Croatia \\ E-mail:〈darko.etinger@unipu.com〉
}

\begin{abstract}
The relevant literature generally views intellectual capital as comprising three components - human, relational and structural capital. These components are identified and classified by their sub-components, meaning that human, relational and structural capital cannot be observed separately. Whereas human capital is most often treated for its frequent identification with intellectual capital and less often with relational capital, this paper we discuss structural capital and, in particular, as one of the sub-components that refers to information technology (IT). The relevant literature views an IT subcomponent as an integral part of almost any classification of structural capital. IT items are intertwined with and are complementary to specific human and relational capital items, and it is common to observe them under the same light. However, because of its presumed importance and influence on other forms of intellectual capital and financial performance, this paper will derive IT from structural capital and treat it as a component that supports the other ones. We still assume that intellectual capital is a logical entity consisting of the three mentioned components, but our intention is also to highlight and prove the importance of IT. Our assumptions were tested in a model under several hypotheses, and most of them were supported. The model is derived from a study conducted on a random sample of Croatian businesses, by applying PLS-SEM and importance-performance analysis.
\end{abstract}

Keywords: information technology (IT), partial least squares structural equation modeling (PLS-SEM), importance-performance analysis, intellectual capital, business performance

Received: September 30, 2016; accepted: December 17, 2016; available online: December 30,2016

DOI: 10.17535 /crorr.2016.0026

\footnotetext{
$\dagger^{\dagger}$ Corresponding author 


\section{Introduction}

Today, intellectual capital is considered one of the main influential factors in the development, success and competitiveness of businesses. In addition, the concept of intellectual capital is the subject of research in several disciplines, such as management, human resource management, finance, marketing, law, intellectual property, information technology, accounting, etc. This wide interest and many aspects of intellectual capital, confirms its role and importance, but also leads to a number of different terms and definitions of it. Thus, it is not uncommon for intellectual capital to be identified with intangibles such as intangible assets, invisible assets, intangible capital, intangible sources or intangible values, intellectual property, intellectual assets, knowledge assets, human capital, information capital, the hidden value of business and other aspects. If we choose to use the term intellectual capital, there are still a number of different definitions and perspectives for the same expression.

Regardless of the perspective, intellectual capital is mostly defined and considered in the relevant literature through its intangible nature and the difficulties in determining its value.

This latter is especially prevalent in accounting. The point is that if an accounting and financial category or item is to be evaluated, recognized and disclosed, meaning if it considered through the main elements of accounting processes, then it becomes necessary to know exactly what it involves and what exactly is to be evaluated and disclosed. It follows that a definition of intellectual capital and its components should be clearly stated. One of the most common ways of defining intellectual capital is describing it in terms of value creation, and also the development and strengthening of a company's competitiveness. Besides that, this paper also presents the acceptance and consideration of the dynamic nature of intellectual capital and its role in creating value, definitions that describe and emphasize flows, connections and relations between intellectual capital components, as well as interaction between intellectual capital and sources in the immediate and wider environment. Besides the mentioned definitions of intellectual capital, Edvinsson explains it in a very simple and unambiguous way, stating that "... the word intellect, is derived from the Latin words inter, meaning between and implying relations, and lectio, meaning reading and acquired knowledge, and from the word capital, meaning a sum total. Intellectual capital is a concept of condensed, relations-based structured knowledge and competencies with development and value-generating potential. It is important because it has probably become the most powerful value generator in the economy of today" [5 p. 124]. Although this is a simple and basic interpretation of the original meaning, we consider this definition adequate as it combines the potential of value creation, as well as the totality of knowledge and relations which determine the value creation process. This kind of definition emphasizes intellectual activities, 
relationships and connections between intellectual capital components and the assumption that the value of intellectual capital lies in its use, which is also one of the main points in our research. In this interaction, each component of intellectual capital has an important and strategic role in creating value and a business's success. Regardless of the different definitions and classifications of intellectual capital, or the lack of clear boundaries between the individual components of capital, most classifications in the relevant literature view intellectual capital through a comprising three components - human, structural and relational capital.

Human capital is usually considered an intellectual capital actuator representing the overall range of individual and collective knowledge and education, skills and competency, as well as other individual characteristics such as employee responsibility, motivation, creativity, innovation, loyalty, experience and other aspects. It is important to emphasize that employees are not human capital themselves, but become human capital only when they transform their knowledge and skills, or their individual characteristics, into actions aligned with business strategy, contributing at the same time to the creation of tangible and intangible value in a business entity" [4]. In fact, this means that employees generate intellectual capital based on their competencies, attitudes and intellectual agility [7] [15].

There are even more definitions and classifications emphasizing the individual nature of intellectual capital, but the creation of new or improving existing knowledge also depends on interactions, connections and relationships between individuals. Besides that, some skills are developed only in an organizational and collective context. Therefore, human capital should be considered on an individual and collective basis. Complementing the concept of human capital, the mentioned individual characteristics can be observed as sub-components of human capital, and their interrelation and actions contribute to structure, significance and success and human capital. It is important to emphasize that various structures and contents of human capital are just illustrative examples and that human capital should contain different sub-components, depending on the particular business. Structural capital is usually considered as being human capital infrastructural support but also as a business's overall tangible and intangible infrastructure that facilitates business processes. Only structural capital, in the form of an intellectual capital component, is owned and controlled by a business. It is also very often described as a set of items that remain in a business after the employees leave. Hence, Stewart [11] explains structural capital as technology, manuals, networks, processes and their descriptions, which allow the storing of knowledge and competences such that they remain in the business after employees leave.

Because of the material part of sub-components (buildings or technological equipment), it is easier to observe and understand it from an accounting point of 
view, in comparison to other intellectual capital components. After all, Ross, Pike and Fernström [15] state that structural capital "may and may not" be shown in the balance sheet. A number of structural capital sub-components can be found in literature, such as patents, licenses, manuals, databases, culture, usable ideas, tasks performing, systems, processes [20], strategies and a business's policies [18]. Some of mentioned items are also part of intellectual property and organizational processes [17] alongside copyrights, franchises, software and organizational culture. In considering the mentioned sub-components, we will adhere to Bontis's [2] definition of structural capital as comprising all the mechanisms and structures that support and help employees to develop and better allocate their cognitive resources and thus improve a business's performance. But as Bontis noted, for the case that a business does not have enough good systems and procedures in place to facilitate intellectual capital activities, the entire intellectual capital of the business is not achievable [7 p. 288].

While human capital is sometimes considered identical to intellectual capital, and structural capital fairly comprehensive in its content, relation capital is much easier to understand. As the term suggests, the meaning and definitions are not just based on relationships and knowledge exchange between entities in a business, but also on relationships and the exchanging of knowledge between businesses and entities outside the environment. It is very often identified with customer capital, but according to its sub-components, relation capital is clearly a much wider concept. Therefore, good communication within a business impacts the success of communication and relationships with entities outside the environment. Unlike structural capital, relation capital sub-components are not always owned by a business, but have a long-term influence on the mentioned relationships.

Relational capital sub-components imply business networks, sale, marketing and distribution networks, electronic networks, relations with clients, suppliers and distributors, business interest groups, brands, corporate image, the ability to attract customers, consumers, relations and communication with present and future consumers in order to achieve satisfaction and loyalty [17 p.46]. Similar sub-components are listed by Roos and Roos [13 p.32], Itami [13 p.32], while Roos, Pike and Fernström [15 p.75] also add the relationship for unions, universities as new knowledge sources, owners, media, local and state government, legislative subjects, and so on.

\section{Literature review and theoretical framework}

\subsection{Research background}

While human capital is mostly discussed as it is frequent identification with intellectual capital, followed by relational capital, we refer to structural capital and especially one of its sub-components in terms of information technology (IT). 
According to the European Information Technology Observatory [13], IT in the broadest sense covers information and communications technologies. Information technology includes hardware, data processing equipment, data communications equipment, software and services, while the communication technology refers to telecommunications equipment and telecommunications services. Usually all these items can be found or implied by some intellectual or structural capital classification.

As mentioned above, structural capital is a broad concept referring to a business's entire tangible and intangible infrastructure that facilitates business processes. Based on different classifications of the sub-components of intellectual capital in the relevant literature, the IT sub-component is an integral part of almost any structural capital classification.

For illustration purposes, Sundać and Švast [17 p.43] also include software, databases and information-communications systems among structural capital sub-components. Marr [13., p. 33] mentions IT systems, Roos, Pike and Fernström [15 p.19, p. 76] refer to information in databases and software, whereas Joia $[11$ p.20] includes operating systems, infrastructures used for informing and communicating. This list is not final, while some classifications include only "IT". Information technology also come under certain intellectual capital definitions. Mouritsen et al [3 p. 615] point out that intellectual capital activates employees, consumers, information technology, managerial actions and knowledge. Davenport and Prusak observe intellectual capital in the context of technology, technological changes and other aspects relating to information technology management, while pointing out the fact that business capable of utilizing technology in information management and processing will also be capable of utilizing intellectual capital for bringing benefits [3 p. 615]. Similarly, Stewart also associates intellectual capital with managing information technology in creating wealth [3 p. 615].

Although IT is an essential part of structural capital, due to its presumed importance and significant influence on other forms of intellectual capital and on business performance, in this paper we will device it from structural capital and view it as a facilitating component.

We still assume that intellectual capital is a logical entity consisting of the three mentioned components, but at the same time, we want to highlight and prove the important influence of the IT component not only within the structural capital, but also in relation to other intellectual capital components and business performance, including innovativeness and market recognition. Besides that, the IT component includes tangible and intangible items, which supports the idea to observe its' role in intellectual capital concept more detail.

In the relevant literature, Toivonen, Smedlund and Järvenpää [19] examine and prove the contribution of IT systems and tools for the emergence and use of different types of knowledge in a business. But keeping in mind that accumulated knowledge is very often considered a part of, and even synonym for intellectual 
capital, the explanation of their study in fact places IT in the context of relational, human, and anyhow, structural capital.

IT infrastructure gives quick and easy access to external sources of knowledge and to new communication channels with partner organizations, increasing both a business efficiency and innovation [11]. This assumption leads to a link between relational capital and IT as being part of structural capital. Moreover, IT increases possibilities for human interaction, while implying that the "human touch" [19] needs to be added to some IT tools. Accordingly, human capital is not only influenced by IT, but also a part of IT which cannot function without a human capital presence. Furthermore, as Toivonen, Smedlund and Järvenpää states [19], referring to several research conclusions, the contribution of IT depends on its utilization. Therefore, the conclusion is that IT is part of structural capital which impacts human, relational, and structural capital. On the other hand, IT will not give any results unless there is cooperation with other intellectual capital construct. For illustration purposes, human capital is necessary when using computers, whereby employees communicate via e-mail as a kind of relation capital communication.

Kianto and Kosonen [12] examined the role of information technology and social capital in intellectual capital, focusing on how intellectual capital is generated in information technology-enabled communication. They also propose future research on the convergence of social capital, information technology and intellectual capital. Soriano, Mas - Tur and Roig - Tierno [16], studied information and communication technologies separately from intellectual capital. Their assumption is that such technologies encourage businesses to build intellectual capital. Based on their conclusions it could be emphasized that such technology does not affect all intellectual capital components equally and that its effect depends on business entity's life cycle. One of the latest theoretical models, although not intended to measuring intellectual capital or intangibles of a business but used to determine relationships within the intellectual capital and value creation of the business entity was proposed by Mhedhbi (2013) from investigations into a sample of Tunisian businesses. The author confirmed the hypotheses on the mutual influence of intellectual capital components, and the influence of intellectual capital on value creation in businesses.

Our research also adheres to the dynamic intellectual capital perspective, indicating that it is still not possible to evaluate the extent of intellectual capital in exact amount or in traditional accounting manner but we can find out its' contextual value. Besides that, according to the mentioned selected examples from previous studies and theoretical assumptions on the position, importance and influence of IT, in our model we extract IT from structural capital and observe it as component which supports and impacts the other ones, as well as innovativeness and market recognition. 


\subsection{Research hypotheses and model construction}

To test our assumption that IT can be derived from structural capital and observed as a component that supports other intellectual capital components, including innovativeness, market recognition, and business performance, and also the assumption that there is a relationship between intellectual capital components and flows creating contextual value of intellectual capital, we have set following hypotheses:

H1a. Information technology has a positive effect on Innovativeness

H1b. Information technology has a positive effect on Relational Capital.

H1c. Information technology has a positive effect on Structural Capital.

H2a. Structural Capital has a positive effect on Relational Capital.

H2b. Structural Capital has a positive effect on Human Capital.

H3. Relational Capital has a positive effect on Human Capital.

H4a. Innovativeness has a positive effect on Business Performance.

H4b. Human Capital has a positive effect on Business Performance.

All these hypotheses are also shown in Figure 1. In this hypothesized model, each hypothesis is represented by a one-way arrow between the constructs - intellectual capital components, IT, innovativeness and business performance. This kind of model supports the idea that intellectual capital value is generated through its usage and can be defined by the interrelationship and interaction of its components.

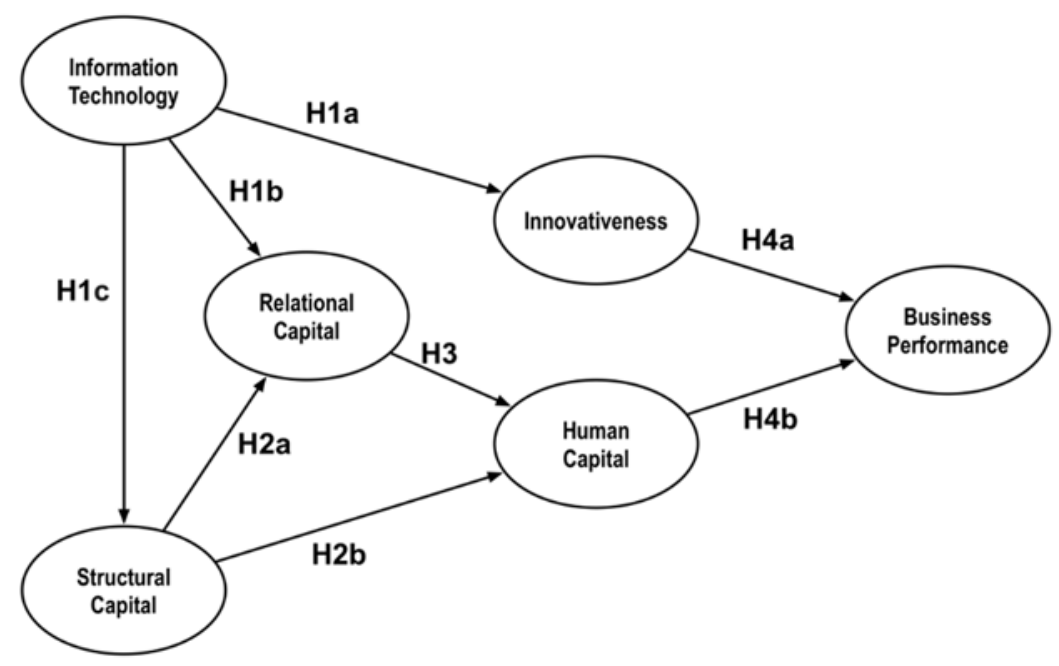

Source: Authors' calculations

Figure 1: Research model 


\section{Research method and analysis of result}

\subsection{Research sample}

To determine relationships between intellectual capital components, and the derived IT component, and the impact of these components on business performance, including the impact of IT on innovativeness and market recognition, research was done on a sample of Croatian businesses by surveying and processing secondary data. Data was collected using a questionnaire. The questionnaire contained multiple choice questions (to collect information on the characteristics of businesses) and the Likert scale (to collect data for human, structural and relational component). Data referring to the performance of businesses in the sample was obtained by processing the data from financial statements available on secondary sources such as the Financial Agency, Zagreb Stock Exchange, business portals or the business's actual website. In developing the survey, the construct indicators were adapted from previous instruments based on a review of the literature and also as the researchers' original proposal. Each question was tailored to the context of the study (shown in Table 1). The survey items relating to each of the constructs in the model were measured using a five-point Likert scale. All the items ranged from 1 (strongly disagree) to 5 (strongly agree). Hence, each intellectual capital component, IT, innovativeness and business performance was represented by a few indicators.

\begin{tabular}{|l|l|l|}
\hline Construct & Indicator & Description \\
\hline \multicolumn{2}{|l|}{ Information Technology } & $\begin{array}{l}\text { A business is characterized by high } \\
\text { technological equipment and continuous } \\
\text { improvement of IT solutions. }\end{array}$ \\
\hline 1 & it1 & $\begin{array}{l}\text { Computer programs and computer systems } \\
\text { have been successfully adapted to the needs of } \\
\text { our business entity. }\end{array}$ \\
\hline 3 & it2 & $\begin{array}{l}\text { The IT system which allows simple, rapid and } \\
\text { unrestricted access to relevant information } \\
\text { and databases is applied in the business. }\end{array}$ \\
\hline Structural Capital & sc1 & $\begin{array}{l}\text { There are good internal links and relationships } \\
\text { between individuals and departments in } \\
\text { businesses. }\end{array}$ \\
\hline 4 & &
\end{tabular}




\begin{tabular}{|c|c|c|}
\hline 5 & $\mathrm{sc} 2$ & $\begin{array}{l}\text { Communication between managers and } \\
\text { employees is very good. }\end{array}$ \\
\hline 6 & sc3 & $\begin{array}{l}\text { All employees are familiar with the } \\
\text { organizational culture, mission and vision. }\end{array}$ \\
\hline 7 & sc4 & $\begin{array}{l}\text { The business's organizing processes in an } \\
\text { enterprise are based on a set strategies and } \\
\text { plans. }\end{array}$ \\
\hline 8 & sc5 & $\begin{array}{l}\text { Corporate strategy is successfully } \\
\text { implemented by achieving strategic goals and } \\
\text { plans. }\end{array}$ \\
\hline \multicolumn{3}{|c|}{ Relational Capital } \\
\hline 9 & $\mathrm{rc1}$ & $\begin{array}{l}\text { Our clients (customers, consumers) are } \\
\text { satisfied with our products and services. }\end{array}$ \\
\hline 10 & $\mathrm{rc} 2$ & $\begin{array}{l}\text { Generally, our clients (customers, users, } \\
\text { consumers) are satisfied with our business } \\
\text { entity and our offer. }\end{array}$ \\
\hline 11 & rc3 & $\begin{array}{l}\text { Customer satisfaction has increased with } \\
\text { respect to the previous year. }\end{array}$ \\
\hline 12 & $\mathrm{rc} 4$ & $\begin{array}{l}\text { The time required to solve problems involving } \\
\text { customer relationships, processing complaints } \\
\text { and responding to the same has been reduced } \\
\text { to a minimum. }\end{array}$ \\
\hline 13 & rc5 & $\begin{array}{l}\text { Research and understanding of customer } \\
\text { desires and needs are the basis for specific } \\
\text { actions and for adapting our products and } \\
\text { services to customer requirements. In other } \\
\text { words, special attention is placed on customer } \\
\text { preferences. }\end{array}$ \\
\hline \multicolumn{3}{|c|}{ Human Capital } \\
\hline 14 & hc1 & $\begin{array}{l}\text { Employees are highly motivated to work and } \\
\text { create. }\end{array}$ \\
\hline 15 & hc2 & Employees are very creative. \\
\hline 16 & hc3 & $\begin{array}{l}\text { Managers at different levels have a high } \\
\text { leadership qualities. }\end{array}$ \\
\hline 17 & hc4 & $\begin{array}{l}\text { Managers at different levels have a high } \\
\text { ability to manage change and adapt to new } \\
\text { market situations. }\end{array}$ \\
\hline 18 & hc5 & $\begin{array}{l}\text { Employees are extremely dedicated to their } \\
\text { work, when performing tasks, they do their } \\
\text { best and show a high level of responsibility in } \\
\text { daily operations. }\end{array}$ \\
\hline
\end{tabular}




\begin{tabular}{|c|c|c|}
\hline \multicolumn{3}{|c|}{ Innovativeness } \\
\hline 22 & inno1 & $\begin{array}{l}\text { Compared to the competition, we have an } \\
\text { innovative advantage in our products and } \\
\text { services. }\end{array}$ \\
\hline 23 & inno2 & $\begin{array}{l}\text { We have a recognizable and positive image in } \\
\text { the market. }\end{array}$ \\
\hline 24 & inno3 & $\begin{array}{l}\text { Our brands are among the leading brands in } \\
\text { the market. }\end{array}$ \\
\hline 25 & inno4 & $\begin{array}{l}\text { We are leaders in introducing and applying } \\
\text { innovation (in production processes, selling } \\
\text { processes, providing services etc.) }\end{array}$ \\
\hline \multicolumn{3}{|c|}{ Business performance } \\
\hline 26 & bperf1 & $\begin{array}{llll}\begin{array}{l}\text { Current } \\
\text { liabilities) }\end{array} & \text { (current assets/current } \\
\end{array}$ \\
\hline 27 & bperf2 & $\begin{array}{l}\text { Coefficient of financial stability I (capital }+ \\
\text { long-term liabilities/long - term assets) }\end{array}$ \\
\hline 28 & bperf3 & $\begin{array}{l}\text { Coefficient of financial stability II (capital + } \\
\text { long-term liabilities/long-term assets + } \\
\text { stock) }\end{array}$ \\
\hline 29 & bperf4 & $\begin{array}{l}\text { Quick ratio (current assets - stocks/current } \\
\text { liabilities) }\end{array}$ \\
\hline 30 & bperf5 & $\begin{array}{l}\text { Return on Assets (profit + interest/average of } \\
\text { assets) }\end{array}$ \\
\hline
\end{tabular}

Source: Authors' calculations

Table 1: Questionnaire elements representing the construct indicators

\subsection{Research methodology and model assessment}

This study is based on the partial least squares structural equation modeling (PLS-SEM) method. SmartPLS 3 [14] as a software tool was used to assess the measurement and structural model. Hair et al. [9] point out that PLS-SEM maximizes the explained variance of the endogenous latent variables by estimating partial model relationships in an iterative sequence of ordinary least squares (OLS) regressions. An important characteristic of PLS-SEM is that it estimates latent variable scores as exact linear combinations of their associated manifest variables [9, from: Fornell and Bookstein, 1982] and treats them as perfect substitutes for the manifest variables.

The research model was assessed using a two-step approach. First, the measurement model was analyzed following the structural model analysis. Hair et al. [8] state that the assessment of reflective outer models involves determining indicator reliability (squared standardized outer loadings), internal consistency 
reliability (composite reliability), convergent validity (average variance extracted, AVE), and discriminant validity (Fornell-Larcker criterion, cross-loadings).

The factor structure matrix of item loadings and cross-loadings is shown in Table 2. The convergent validity of each construct is achieved as the item loadings for each construct are above the threshold of 0,708 [10].

\begin{tabular}{|l|l|l|l|l|l|l|}
\hline & $\begin{array}{l}\text { Busi- } \\
\text { ness } \\
\text { Perfo- } \\
\text { rmance }\end{array}$ & $\begin{array}{l}\text { Human } \\
\text { Capital }\end{array}$ & $\begin{array}{l}\text { Innova- } \\
\text { tiveness }\end{array}$ & $\begin{array}{l}\text { Informa- } \\
\text { tion } \\
\text { Techno- } \\
\text { logy }\end{array}$ & $\begin{array}{l}\text { Relati- } \\
\text { onal } \\
\text { Capital }\end{array}$ & $\begin{array}{l}\text { Stru- } \\
\text { ctural } \\
\text { Capital }\end{array}$ \\
\hline bperf1 & $\mathbf{0 . 8 1 4}$ & 0.287 & 0.066 & 0.137 & 0.149 & 0.124 \\
\hline bperf2 & $\mathbf{0 . 7 7 8}$ & 0.232 & -0.093 & 0.078 & -0.005 & 0.123 \\
\hline bperf3 & $\mathbf{0 . 7 8 3}$ & 0.233 & -0.091 & 0.100 & 0.030 & 0.115 \\
\hline bperf4 & $\mathbf{0 . 8 4 2}$ & 0.384 & 0.068 & 0.213 & 0.255 & 0.159 \\
\hline bperf5 & $\mathbf{0 . 7 1 4}$ & 0.215 & 0.001 & 0.057 & 0.058 & 0.086 \\
\hline hc1 & 0.344 & $\mathbf{0 . 8 4 2}$ & 0.229 & 0.417 & 0.432 & 0.444 \\
\hline hc2 & 0.311 & $\mathbf{0 . 8 2 1}$ & 0.198 & 0.361 & 0.398 & 0.428 \\
\hline hc3 & 0.28 & $\mathbf{0 . 8 1 7}$ & 0.158 & 0.368 & 0.437 & 0.493 \\
\hline hc4 & 0.265 & $\mathbf{0 . 8 0 0}$ & 0.101 & 0.343 & 0.528 & 0.426 \\
\hline hc5 & 0.254 & $\mathbf{0 . 8 1 6}$ & 0.015 & 0.349 & 0.437 & 0.404 \\
\hline inno1 & -0.062 & 0.196 & $\mathbf{0 . 7 3 2}$ & 0.460 & 0.264 & 0.292 \\
\hline inno2 & -0.023 & 0.121 & $\mathbf{0 . 7 4 3}$ & 0.320 & 0.491 & 0.312 \\
\hline inno3 & 0.043 & 0.106 & $\mathbf{0 . 8 6 0}$ & 0.500 & 0.394 & 0.278 \\
\hline inno4 & 0.020 & 0.140 & $\mathbf{0 . 8 8 4}$ & 0.572 & 0.396 & 0.357 \\
\hline it1 & 0.204 & 0.418 & 0.620 & $\mathbf{0 . 9 2 4}$ & 0.395 & 0.291 \\
\hline it2 & 0.063 & 0.381 & 0.358 & $\mathbf{0 . 8 7 2}$ & 0.341 & 0.224 \\
\hline it3 & 0.146 & 0.421 & 0.576 & $\mathbf{0 . 9 2 6}$ & 0.502 & 0.368 \\
\hline rc1 & 0.091 & 0.482 & 0.187 & 0.287 & $\mathbf{0 . 8 0 3}$ & 0.364 \\
\hline rc2 & 0.060 & 0.429 & 0.523 & 0.427 & $\mathbf{0 . 7 7 7}$ & 0.477 \\
\hline rc3 & 0.145 & 0.416 & 0.443 & 0.374 & $\mathbf{0 . 7 1 9}$ & 0.341 \\
\hline rc4 & 0.202 & 0.434 & 0.188 & 0.240 & $\mathbf{0 . 7 3 9}$ & 0.386 \\
\hline rc5 & 0.046 & 0.275 & 0.383 & 0.414 & $\mathbf{0 . 7 1 7}$ & 0.362 \\
\hline sc1 & 0.116 & 0.407 & 0.132 & 0.204 & 0.322 & $\mathbf{0 . 7 9 2}$ \\
\hline sc2 & 0.129 & 0.597 & 0.050 & 0.187 & 0.342 & $\mathbf{0 . 7 4 9}$ \\
\hline sc3 & 0.095 & 0.291 & 0.301 & 0.178 & 0.286 & $\mathbf{0 . 8 4 9}$ \\
\hline sc4 & 0.145 & 0.390 & 0.428 & 0.306 & 0.508 & $\mathbf{0 . 8 8 7}$ \\
\hline sc5 & 0.138 & 0.429 & 0.555 & 0.407 & 0.543 & $\mathbf{0 . 7 7 6}$ \\
\hline & & & & & & \\
\hline & & & & & \\
\hline
\end{tabular}

Source: Authors' calculations

Table 2: The factor structure matrix of item loadings and cross-loadings 
Verification of the indicators reliability was obtained by calculating Cronbach's Alpha coefficient (CA), Composite reliability (CR) and the Average Variance Extracted (AVE) for the reflective constructs (shown in Table 3.). Human Capital, Relation Capital, Structural Capital, IT, Innovativeness and Market Recognition, and Business Performance all exhibit sufficient reliability given that the calculated values exceed the threshold ( $\mathrm{CA}>0,7, \mathrm{CR}>0,7, \mathrm{AVE}>0,5)$. To confirm the discriminant validity among constructs (Fornell-Lacker criterion) the AVE square root must be superior to the correlation between constructs. Results in Table 3. indicate that discriminant validity was established.

\begin{tabular}{|c|c|c|c|c|c|c|c|c|c|}
\hline Construct & $\mathrm{CA}$ & $\mathrm{CR}$ & AVE & (1) & (2) & (3) & (4) & (5) & (6) \\
\hline $\begin{array}{l}\text { Business } \\
\text { Performa- } \\
\text { nce (1) }\end{array}$ & 0.849 & 0.89 & 0.62 & 0.787 & & & & & \\
\hline $\begin{array}{l}\text { Human } \\
\text { Capital (2) }\end{array}$ & 0.877 & 0.911 & 0.671 & 0.356 & 0.819 & & & & \\
\hline $\begin{array}{l}\text { Innovati- } \\
\text { veness (3) }\end{array}$ & 0.822 & 0.882 & 0.653 & -0.002 & 0.173 & 0.808 & & & \\
\hline $\begin{array}{l}\text { Informa- } \\
\text { tion } \\
\text { Technology } \\
\text { (4) }\end{array}$ & 0.895 & 0.933 & 0.824 & 0.161 & 0.449 & 0.59 & 0.908 & & \\
\hline $\begin{array}{l}\text { Relational } \\
\text { Capital (5) }\end{array}$ & 0.808 & 0.866 & 0.565 & 0.143 & 0.546 & 0.465 & 0.464 & 0.752 & \\
\hline $\begin{array}{l}\text { Structural } \\
\text { Capital (6) }\end{array}$ & 0.871 & 0.906 & 0.66 & 0.158 & 0.537 & 0.382 & 0.334 & 0.517 & 0.812 \\
\hline
\end{tabular}

*square root of AVE on diagonal

Source: Authors' calculations

Table 3: Discriminant validity of the constructs

After establishing the reliability of the indicators and the convergent and discriminant validity of the constructs, we examined the structural model. The results of PLS analysis for the hypotheses are shown in Figure 2. 


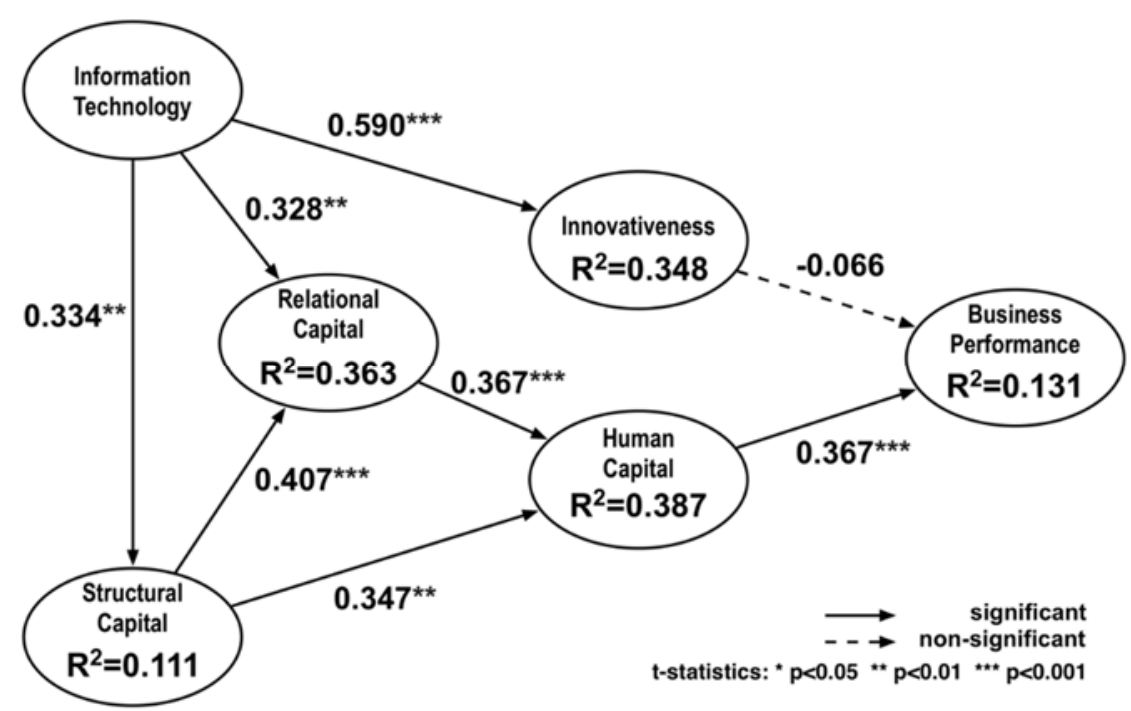

Source: Authors' calculations

Figure 2: Structural model results

As already mentioned, we have extracted IT from structural capital and now examine its impact on business performance separately, and also its influence on intellectual capital itself, that is, on other intellectual capital components. As we assume that IT supports all three components, and that it is interrelated with each of them, and does not function without them, it is considered a starting point in setting the hypothesized relations.

Our model and hypotheses can be explained under the assumption that developed information and technological infrastructure, which allows fast and unlimited access to relevant information and databases, has a positive effect on the implementation of corporate strategy, planning processes based on strategies and plans, and employee awareness of the organization's culture, mission and vision. Consequently, this kind of IT infrastructure should support communication in businesses, leading to a better impact of IT on structural capital components (Hc1). Furthermore, the described IT and familiarity with a business's strategies and goals, has a positive effect on improving customer satisfaction (H1b; H2a). Implementation and enforcement of corporate strategy and employee awareness of the mission and vision has a positive effect on managerial leadership skills and the ability to adapt to new market situations, as well as employee motivation, creativity and commitment (H2b). In addition, the mentioned managerial skills and employee traits are also positively affected by efforts in maintaining high levels of customer satisfaction (H3). It is supposed that efforts in customer relationship and customer satisfaction as expected feedback motivates employees to be more committed and interested in business entity's goals and strategies. 
Our main hypothesis is that intellectual capital value is generated in its utilization (a dynamic approach), that is, in interrelationship with its component, now additionally influenced by interaction with IT. It was assumed that human capital, after being directly influenced by structural and relational capital, and indirectly by IT, has a direct, positive and significant impact on financial indicators of liquidity, solvency, activity and profitability representing a construct of business performance. This relation is shown using hypothesis $\mathbf{H} 4 \mathbf{b}$, and is supported in the model. On the other hand, structural capital, IT and relational capital, have an indirect impact on business performance. The chosen financial indicators are important not only for indicating the capability of paying debts, or increasing invested funds but also in indicating business success. Consequently, knowing the impact of intellectual capital on liquidity, solvency and activity, as well as profitability can be very important and useful for analyzing and planning the future business performance of a specific business entity. Hence, information on the impact of intellectual capital on those indicators can be of great assistance when analyzing past results and making decisions for the future of the business. We also expanded the model with the construct Innovativeness. Innovations and market recognition are view together as a better market and brand position requires a certain level of innovation in business operations.

Although the construct is often classified as structural capital, we can also observed it separately. The assumption is and there is support (H1a) that developed and improved IT solutions, as well as adapted computer systems and unrestricted, rapid and simple access to information, have a significant positive effect on the advantages of and a leading innovative position, as well as a business's leading position for its brands and recognizable market image. But this innovativeness has not positive and significant influence on business performance (H4a). Hence, the conclusion is that the construct should not be extracted from other intellectual capital components and observed separately, as it is more likely that its influence will be greater if belonging to structural and relational components. Consequently, although IT does not have a significant positive and indirect influence in innovativeness, indirectly it has a significant positive influence on business performance in terms of intellectual capital components, which proves our presumption of the important of IT and reason to observe it as an extracted construct.

\begin{tabular}{|l|l|l|l|}
\hline Hypotheses & $\begin{array}{l}\text { Path } \\
\text { Coefficients }\end{array}$ & $\begin{array}{l}\text { t- } \\
\text { value }\end{array}$ & Supported? \\
\hline $\begin{array}{l}\text { H1a. Information } \\
\text { Technology } \rightarrow \text { Innovativeness }\end{array}$ & 0.59 & 9.132 & $\begin{array}{l}\text { Yes, } \\
\mathrm{p}<0.001\end{array}$ \\
\hline $\begin{array}{l}\text { H1b. Information } \\
\text { Technology } \rightarrow \text { Relational Capital }\end{array}$ & 0.328 & 3.428 & $\begin{array}{l}\text { Yes, } \\
\mathrm{p}<0.01\end{array}$ \\
\hline
\end{tabular}




\begin{tabular}{|l|l|l|l|}
\hline $\begin{array}{l}\text { H1c. Information } \\
\text { Technology } \rightarrow \text { Structural Capital }\end{array}$ & 0.334 & 3.389 & $\begin{array}{l}\text { Yes, } \\
\mathrm{p}<0.01\end{array}$ \\
\hline $\begin{array}{l}\text { H2a. Structural } \\
\text { Capital } \rightarrow \text { Relational Capital }\end{array}$ & 0.407 & 3.74 & $\begin{array}{l}\text { Yes, } \\
\mathrm{p}<0.001\end{array}$ \\
\hline $\begin{array}{l}\text { H2b. Structural } \\
\text { Capital } \rightarrow \text { Human Capital }\end{array}$ & 0.347 & 3.085 & $\begin{array}{l}\text { Yes, } \\
\mathrm{p}<0.01\end{array}$ \\
\hline $\begin{array}{l}\text { H3. Relational } \\
\text { Capital } \rightarrow \text { Human Capital }\end{array}$ & 0.367 & 4.224 & $\begin{array}{l}\text { Yes, } \\
\mathrm{p}<0.001\end{array}$ \\
\hline $\begin{array}{l}\text { H4a. Innovativeness } \\
\rightarrow \text { Business Performance }\end{array}$ & -0.066 & 0.54 & No \\
\hline $\begin{array}{l}\text { H4b. Human Capital } \\
\rightarrow \text { Business Performance }\end{array}$ & 0.367 & 4.179 & $\begin{array}{l}\text { Yes, } \\
\mathrm{p}<0.001\end{array}$ \\
\hline
\end{tabular}

Source: Authors' calculations

Table 4: Summary of test results for the structural model.

Finally, our structural model shows a significant positive relationship between all constructs except for the relationship between Innovativeness and Business Performance. Therefore, hypotheses H1a, H1b, H1c, H2a, H2b, H3 and H4b are all supported (detailed report shown in Table 4.). The hypothesis H4a is found to be negative and not significant, and is therefore rejected. Besides the direct influence of human capital on financial indicators which equates to business performance, the indirect influence of structural and relational capital on business performance is also evident as shown in Figure 2.

\section{Importance-performance matrix analysis}

Importance-performance analysis (IPA) was introduced by Martilla and James (1977) in marketing research to facilitate an understanding of customer satisfaction as a function of both expectations concerning the significant attributes and judgments about their performance [1].

Deng, Kuo \& Chen [6] define importance-performance analysis (IPA) as a simple and effective technique that can be applied to guide quality-based marketing strategies and assist practitioners in prioritizing attributes when enhancing service quality and user satisfaction. Practitioners apply IPA to analyze two dimensions of product/service attributes: performance level (satisfaction); and, importance to users. The analysis of these dimension attributes are then integrated into a matrix that helps identify primary drivers of user satisfaction and, based on these findings, sets improvement priorities, and identifies areas of "possible overkill" and areas of "acceptable" disadvantage [6, from: Matzler et al., 2004]. In other words, importance is seen as a reflection of the relative value of the various quality attributes to consumers. Lower importance ratings are likely to play a lesser role 
in affecting overall perceptions, while higher importance ratings are likely to play a more critical role in determining customer satisfaction.

Hair, Hult, Ringle \& Sarstedt [10] point that for a specific endogenous latent variable representing a key target construct in the analysis, the importanceperformance matrix analysis (IPMA) contrasts the structural model total effects (importance) and the average values of the latent variable scores (performance) to highlight significant areas for the improvement of management activities. The results of IPMA for our model indicators are shown in Table 5.

\begin{tabular}{|l|l|l|}
\hline Indicators & Importance & Performance \\
\hline Human Capital & & \\
\hline hc1 & 0.093 & 68.75 \\
\hline hc2 & 0.086 & 64.062 \\
\hline hc3 & 0.092 & 55.417 \\
\hline hc4 & 0.093 & 62.5 \\
\hline hc5 & 0.083 & 66.667 \\
\hline Innovativeness & & \\
\hline inno1 & -0.02 & 71.562 \\
\hline inno2 & -0.014 & 80.312 \\
\hline inno3 & -0.022 & 68.125 \\
\hline inno4 & -0.025 & 69.688 \\
\hline Information Technology & & \\
\hline it1 & 0.026 & 76.875 \\
\hline it2 & 0.018 & 81.875 \\
\hline it3 & 0.028 & 74.688 \\
\hline Relational Capital & & \\
\hline rc1 & 0.037 & 76.25 \\
\hline rc2 & 0.041 & 74.583 \\
\hline rc3 & 0.035 & 62.5 \\
\hline rc4 & 0.034 & 70.417 \\
\hline rc5 & 0.031 & 58.125 \\
\hline Structural Capital & & \\
\hline sc1 & 0.039 & 63.75 \\
\hline sc2 & 0.049 & 71.562 \\
\hline sc3 & 0.032 & 72.5 \\
\hline sc4 & 0.05 & 70.833 \\
\hline sc5 & 0.056 & 66.25 \\
\hline & & \\
\hline & & \\
\hline
\end{tabular}

Source: Authors' calculations

Table 5: IPMA analysis results 
Analyzed individually, importance and performance data may not be as meaningful as when both data sets are studied simultaneously [1]. Hence, to generate the IPMA, each attribute is placed on a two-dimensional graph axis the importance and performance. Then, a cut through the arithmetic mean of the available data is performed, to obtain the following four portions:

- Quadrant 1: Concentrate here. This field indicates the major uses that are insufficiently perceived by respondents;

- Quadrant 2: Keep up the good work. This field indicates the major uses that are sufficiently received by respondents;

- Quadrant 3: Low priority. These uses are not very well perceived, but they are less valuable to respondents;

- Quadrant 4: Possible overkill. These uses are well perceived, however they are less valuable to respondents.

Ainin and Hishman [1] state that the four quadrants matrix helps organizations to identify the areas for improvement and actions for minimizing the gap between importance and performance. In this case, the conclusion is that businesses need to concentrate on human capital indicators. IT indicators in the "overkill" quadrant, go in line with the presumption that mere investments in IT will not give results if there are no people or procedures on use it and getting benefits from such use.

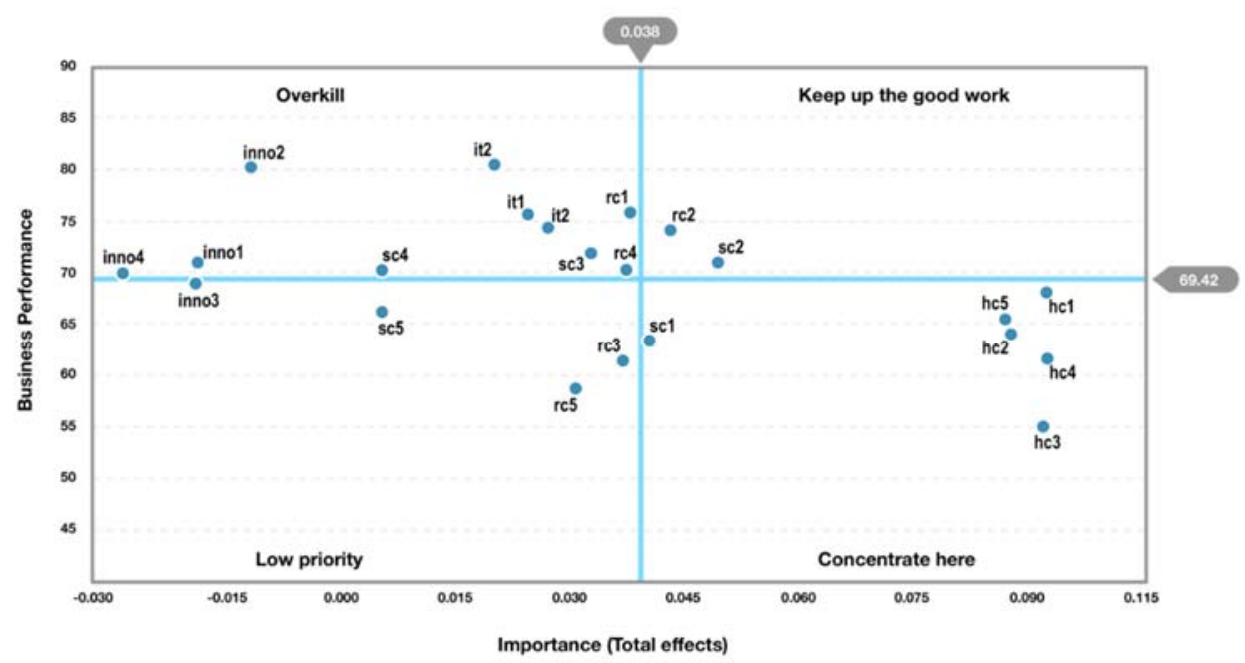

Source: Authors' calculations

Figure 3: IPMA representation 
After performing the IPMA analysis, the total effects and latent variable scores are obtained. The total effects of the constructs indicating the importance are: Human Capital $=0.367$, Innovativeness $=-0.066$, Information Technology $=$ 0.066, Relational Capital $=0.135$ and Structural Capital $=0.182$. The latent variable scores for the constructs indicating the performance are as follows: Human Capital $=63.431$, Innovativeness $=71.944$, Information Technology $=$ 77.589, Relational Capital $=69.144$ and Structural Capital $=68.627$. The IPMA representation is shown in Figure 3.

\section{Concluding remarks}

In our research, we adhered to a dynamic intellectual capital perspective, indicating that it remains impossible to evaluate intellectual capital in its exact amount or in a traditional accounting manner, but it is possible to ascertain its contextual value. In this paper, we referred to structural capital and especially one of its sub-components referring to information technology (IT). According to relevant literature mentioned in this paper, the IT sub-component is an integral part of almost each classification of structural capital. IT items are also intertwined with and complementary to specific human and relational capital items, and it is reasonably to observe them together. But because of its presumed importance and significant influence on all other intellectual capital components, as well as on business performance, in this paper we have extracted IT from structural capital and observed it as a component that supports other components. We have assumed intellectual capital as a logical entity consisting of human, structural and relational capital, but at the same time we wanted to highlight and prove the importance and influence of IT. Although IT is a part of structural capital and impacts human, relational, and structural capital itself, IT will not give any result if there is no cooperation with other intellectual capital construct. Even in the IPMA results, IT indicators are in the "overkill" quadrant, implying that just merely investing in IT will not give results, but that the construct should be in the interaction with other components, in order to get benefits from it. Eight hypotheses were established in this research. Seven of them indicate a significant positive relationship between all constructs, and finally with business performance, except for the relationship between Innovativeness and Business Performance. Consequently, knowing the influence of intellectual capital on liquidity, solvency and activity, as well as profitability can be very important and useful in analyzing and planning for a business's performance. Hence. information on the influence of capital on those indicators can be of great help when analyzing past results and making decisions for future business. In order to establish possible application of the proposed model for the impact of intellectual capital on business performance, with particular emphasis on the impact of IT, future research should test the previously described model on a samples of 
businesses from different industries or other business characteristics. In that cases, it becomes necessary to take into account the specificities of any business and the fact that the value of the indicators in the constructs will be different. This kind of model can show which flows have to be maintained at a significantly high level of activity within each indicator construct. This requires consideration of all indicators, with special focus on the cost of possible activities.

\section{References}

[1] Ainin, S., \& Hisham, N. H. (2008). Applying importance-performance analysis to information systems: an exploratory case study. Journal of Information, Information Technology, and Organizations, 3, 95-103.

[2] Bontis, N. (1998): Intellectual capital: an exploratory study that develops measures and models. Management Decision, MCB University Press, 36, 2, 63-76.

[3] Choong, K.K. (2008). Intellectual capital: definitions, categorization and reporting models. Journal of Intellectual Capital. Emerald Group Publishing Limited, Vol. 9, No. 4., 609-638.

[4] Croatian Chamber of Economy (2004). Priručnik za upravljanje intelektualnim kapitalom u tvrtkama (Manual for Managing Intellectual Capital in Companies). Zagreb: HGK - Zajednica za unapređenje intelektualnog kapitala.

[5] Daum, J.H. (2003). Intangible Assets and Value Creation. New York: John Wiley \& Sons, Inc.

[6] Deng, W.-J., Kuo, Y.-F., \& Chen, W.-C. (2008). Revised importanceperformance analysis: three-factor theory and benchmarking. The Service Industries Journal, 28(1), 37-51.

[7] Engström, T.E.J., Westnes, P., Westnes, S.F. (2003). Evaluating intellectual capital in the hotel industry, Journal of Intellectual Capital, MCB UP Limited, Vol. 4., No. 3., 287 - 303.

[8] Hair, J. F., Sarstedt, M., Ringle, C. M., \& Mena, J. A. (2011). An assessment of the use of partial least squares structural equation modeling in marketing research. Journal of the Academy of Marketing Science, 40(3), 414-433.

[9] Hair, J. F., Sarstedt, M., Ringle, C. M., \& Mena, J. A. (2012). An assessment of the use of partial least squares structural equation modeling in marketing research. Journal of the Academy of Marketing Science, 40(3), 414-433.

[10] Hair J. F., Hult, G. T. M., Ringle C. M., \& Sarstedt, M. (2014). A primer on partial least squares structural equation modeling (PLS-SEM). CA, Los Angeles: Sage Publications Inc.

[11] Joia, L.A. (2007). Strategies for Information Technology and Intellectual Capital - Challenges and Opportunities, Hershey. London: Information Science Reference. 
[12] Kianto, A., Kosonen, M. (2007). Information Technology, Social Capital, and the Generation of Intellectual Capital. In Joia, L.A. (2007). Strategies for Information Technology and Intellectual Capital - Challenges and Opportunities (pp 126-147), Hershey. London: Information Science Reference.

[13] Marr, B. (edit).2005.: Perspectives on Intellectual Capital, Burlington: Elsevier Inc.

[14] Ringle, C. M., Wende, S., and Becker, J.-M. (2015). "SmartPLS 3." Boenningstedt: SmartPLS GmbH. Available at: http://www.smartpls.com. [Accessed 01/09/2016]

[15] Roos, G., Pike, S., Fernström, L. (2005). Managing Intellectual Capital in Practice. Burlington: Elsevier Butterworth - Heineman.

[16] Soriano, D.R., Mas - Tur, A., Roig - Tierno, N. (2015). New ICTs entrepreneurship: which component of intellectual capital should we be promoting? Proceedings of the European Conference on Intellectual Capital. Acadaemic Conferences \& Publishing International Ltd., 298-304.

[17] Sundać, D., Švast, N. (2009). Intelektualni kapital - temeljni čimbenik konkurentnosti poduzeća (Intellectual Capital - A Key Factor of Company Competitiveness). Zagreb: MINGORP.

[18] Swart, J. (2006). Intellectual capital: disentangling an enigmatic concept. Journal of Intellectual Capital, Emerald Group Publishing Limited, Vol. 7., 2006., No. 2., 136-159.

[19] Toivonen, Smedlund, A., Järvenpää, E. (2007). The Impacts of Information Technology on the Stock and Flow of a Firm's Intellectual Capital. In Joia, L.A. (2007). Strategies for Information Technology and Intellectual Capital Challenges and Opportunities (pp 111-125), Hershey. London: Information Science Reference.

[20] Youndt, M.A., Subramaniam, M., Snell, S.A. (2004). Intellectual capital profiles: an examination of investments and returns. Journal of Management Studies, Blackwell Publishing, March, 333-361. 